\title{
Research on the Ethics of War in the Context of Violence in Gaza
}

Howard Adelman

Abstract The paper first demonstrates the ability to provode objective data and analyses during war and then examines the need for such objective gathering of data and analysis in the context of mass violence and war, specifically in the 2009 Gaza War. That data and analysis is required to assess compliance with just war norms in assessing the conduct of the war, a framework quite distinct from human rights norms that can misapply and deform the application of norms such as proportionality and obligations not to target civilians.

Keywords Gaza · Just war - Objectivity - Discrimination · Proportionality - Violence

\section{Introduction}

Though this conference focuses on research with the disadvantaged during times of war and peace, this paper will stray from a narrow interpretation of 'disadvantaged' even though civilians trapped in contemporary asymmetrical wars certainly qualify as disadvantaged. However, the research I discuss is not precisely on them and certainly not with them even when the subject matter is their protection and they are the victims. Over the years, I have undertaken research in refugees camps (Dadaab and Kikuyu in Kenya (Adelman and Abdi 2003; Princeton Refugee Initiative 2005), for example) and on the internally displacedmost recently in Sri Lanka. While such research has attached to it a number of physical risks - from health to murder to which I will briefly refer-the focus of this essay is on a very different group of disadvantaged. They are scholars and researchers who hold to traditional standards of objectivity and fairness as well as an effort to eschew ideology. They specifically reject the proposition that research inherently serves some power interest and is, therefore, by its very nature, biased. ${ }^{1}$ The problem is not that postmodernist and neoMarxist scholars dismiss these traditional views as naïve and old-fashioned. After all, there is very little physical, psychological, social and certainly no political risk coming from

${ }^{1}$ Cf. Foucault (1986); Pease (2002)

Paper for presentation at an International Conference on Research with the Disadvantaged in Times of War and Peace, Montreal, 29-30 May 2009

H. Adelman (*)

York University, Toronto, ON, Canada

e-mail: howardadelman@rogers.com 
those academics with whom they disagree. The risks come from a large number of students who seem increasingly, at least at York University, to have emerged from an inculcation in such views and openly deride and sneer at the idea of objectivity.

On Monday 11 May 2009, I was a last minute substitute on a panel debating whether academic boycotts were justified and appropriate. The background of the debate was the campaign to boycott Israeli academic institutions currently underway around the world and given much greater propulsion following the Gaza War that ended in a cease fire on 18 January 2009. Though I dislike debates as a format generally, I reluctantly agreed to appear on the nay side. The debate itself was polite, even though there were two totally different subject matters. ${ }^{2}$ The ayes insisted that, given the self-evident crimes of the Israelis in the conduct of the war, which they spent most of their time asserting, and given what they contended was the complicity of Israeli academic institutions in those crimes, a boycott was justified in the name of the academic freedom of Palestinians, although Abi Bakan, a professor of sociology at Queens University (whose parents had both been close colleagues of mine) kept insisting that supporting an academic boycott was not antisemitic even though the nays never once made such a charge. Instead, my colleague from the University of Western Ontario, who heads an organization to uphold academic freedom generally, kept to the issue of academic freedom and defended its universal application while I, without any previous coordination with my partner on the nay side, specifically cited heads of Palestinian institutions (Sari Nusseibah, President of al Quds University) and institutional formal arrangements between Palestinian post-secondary institutions and Israeli ones promoting exchanges and cooperation as well as Palestinian or pro-Palestinian research that also demonstrated the benefits of those relationships. ${ }^{3}$

Although the debate was chaired with great fairness and the tone of the debate was cool and detached, even if the material was often emotionally charged-Israel was a racist and apartheid state-when the audience participation began, most questions simply became opportunities to make further claims about the activities of Israel as a prologue to a question, beginning with the first questioner who painted Israel as simply defending itself from extremists determined to wipe it off the map. The vast majority of the questioners, and the audience for that matter if the cheers and boos had been measured, simply piled on claim after claim on the viciousness of Israel as a state often with derision and sneers at the minority who took the nay side in the debate.

However, an unpleasant experience with a group of students-and many perhaps were not even students in the classical definition-is not novel. What did seem novel was the fading away of civility in the discourse at an academic institution. My own memories of radical politics in the sixties was that, no matter how heated the issue-nuclear disarmament, racism in the American south, the War in Vietnam-the discourse had remained civil, though it is possible that I suffer from early Alzheimers and/or a distorted and rosy view of that history.

\footnotetext{
2 "A Debate on the Academic Boycott of Israel," York University, 11 May 2009.

${ }^{3}$ Walis Salem and the late Edy Kaufman wrote a set of guiding principles for Israeli/Palestinian Academic Cooperation for UNESCO: "Translating Shared Adherence to Academic Freedom into Action" dedicated to "significantly increasing the percentage of Israeli and Palestinian academics and intellectuals engaged in constructive dialogue" and set out a shared set of principles that excluded boycotting academic institutions and to build on the developing shared "Arab-Israeli Research Cooperation 1995-1999" (see Meria 4:3, 2000, 1-6) that had developed before the outbreak of the second intifadah. See also the Rome Principles signed at the University of Rome, La Spienza in May 2004 by the rectors and presidents of five Israeli and four Palestinian universities and research institutes. Essentially, they were influenced by the Faculty for IsraeliPalestinian Peace (FFIPP) advocating "the meaningful reconciliation between conflicting ethnic groups and denominations through joint educational and cultural projects". (23-4) and was rooted in the UN Declaration of Human Rights, the principles of academic freedom of the International Association of Universities and the Constitution of UNESCO.
} 
This long-winded introductory narrative is but a prologue to my subject matter-the risk to scholars attempting to undertake research in a sphere of violent conflict. Though I will refer briefly to some examples of physical risks taken in the past, this essay is focussed on the difficulties of conducting such research in an atmosphere that is not only highly charged emotionally, but one which carries with it a built-in justification that identification with those suffering the most-in this case the Palestinians in Gaza-somehow warrants eschewing efforts at factual accuracy and as much objectivity as possible in interpretation and analysis in favour of partisan accounts. These partisan accounts come from some of the foremost agencies who work with or are advocates on behalf of the disadvantaged and those whose rights are abused. This essay deals with undertaking research on just war theory, more particularly ius in bello ethical norms in the conduct of war, with particular reference to the principle of proportionality and the obligation of combatants towards the protection of civilians in such wars and the Gaza War in particular. Since my experience suggests that war just adds enormously to the difficulty, I will ignore the difference between whether extensive actual fighting is underway or not, for in asymmetrical warfare of this type that is now so prevalent, the surcease from battle is usually only the opportunity to prepare for the next (Downs and Stedman (2001)). Extensive battles merely add greatly to the difficulties but do not alter the basic problem of conducting the research.

\section{General Background}

When I headed the Refugee Documentation Project at York University in the early eighties following my active involvement with the private sponsorship movement for Indochinese refugees, philosophy, my discipline, seemed to have been shunted aside. One of my first concerns in dealing with Indochinese refugees had been the propensity to exaggerate and distort not only narratives but even basic facts about numbers to advance a cause. For example, I began to keep a record of my interviews with and appearances on the media to measure my account of how Operation Lifeline had started and the media reporting of that event. In my account, it had been a suggestion of government officials that we begin with the private sponsorship of refugees, an act of witnessing, rather than our idea of a petition to Ron Atkey, the Minister of Employment and Immigration in 1979. The initiative which led to the creation of Operation Lifeline first appeared in a distorted story by Dick Beddoes, a Globe and Mail columnist, who was actually the individual who dubbed our little group, Operation Lifeline, and portrayed us as a crusade to pressure the government to take in more refugees. In fact, the Clark Tory government had actively been seeking private sector partners to increase the intake. In 166 interviews on Operation Lifeline, after repeatedly ignoring my efforts to correct the by now official media account, we were portrayed as a pressure and advocacy movement that had succeeded in getting the government to take more and more refugees. The media were unwavering. We were the grassroots organization that got the inert government to act, with the implicit message that the media campaign had helped. That story was very far from the truth (Adelman 1982a). Though the organization was our initiative and took advantage of Dick Beddoes' publicity, the whole idea of sponsorship was a government idea. Further, the government was at least as eager to increase the intake as we were.

The lessons in distortion continued. As a documentation project, we became acutely aware that refugee figures were most often exaggerated. In 1982, we were presented with an opportunity to provide evidence that there could be objectivity about basic facts concerning the forcibly displaced even in the context of violent conflict when the Israelis invaded Lebanon in 1982. OXFAM in Britain had taken out full page advertisements claiming 600,000 had been 
made homeless by the Israeli invasion even before Ariel Sharon had taken the war to Beirut. The Israeli government had issued a formal report that the number of homeless was 19,000 based on a survey undertaken by one of Israel's foremost scholars, a scholar on the Bedouin (Bailey 1985). We were determined to demonstrate that, even in the context of war, objective evidence could be obtained about basic facts, the numbers of those made homeless by the war even during the conduct of the war. After some effort and more luck-we found out that my colleague who was then at the University of Tel Aviv, who had conducted the study for Israel, had made an arithmetic error and, even according to his count, the number had been 29,000 not 19,000-we arrived in Lebanon to conduct the research.

With more luck than skill we very quickly learned that the figure of 600,000 had come from an ICRC cable calling for emergency aid since 600,000 civilians had been affected by the Israeli invasion. Second, instead of having to conduct a survey de novo, we learned that twelve different counts of those made homeless by the war had already been undertaken or were being completed. These included ones by the Lebanese Association of Engineers, the Palestinian teachers association, municipal authorities and government offices. Our task became to audit the different counts and reconcile differences rather than undertake a count from scratch. Except for one incident after curfew when we were out interviewing Palestinians and saw a civilian shot when he ran after being spotted by Israeli soldiers, we never felt endangered.

In our audit, we were able to demonstrate that every single one of the counts had attempted to be objective. Distortions crept in by failures in the comprehensiveness of the survey-the Israeli survey had overlooked pockets of homelessness. Or they came from the definition of what 'homelessness' meant. Thus, the Palestinian teachers' count, which was by far the most meticulous, included in its numbers people whose homes in refugee camps had been destroyed but the homes had been rented out to Bangladeshi guest workers while the owners had been away working in the Gulf for years. But the teachers recorded that fact and the actual numbers of Palestinians made homeless-defined as those deprived of shelter by the warcould be accurately counted from their surveys. Ironically, and to the complete surprise of the ICRC, the most accurate count was that undertaken by the ICRC itself which, ashamed of their primitive methodology which they reluctantly disclosed, came to a total of 40,000 made homeless in southern Lebanon, a figure arrived at by counting the number of kitchen kits they distributed and multiplying by three. In reconciling all the counts, we too had arrived at a figure of 40,000 and that figure was subsequently used by all sides as the accurate number of those displaced (Adelman 1982b, c).

The next year we had another opportunity in Sri Lanka. Canada had a policy of accepting Tamil refugees from Sri Lanka who had been threatened by the riots in Colombo in 1982. We interviewed claimants -6 in all-who had been refused asylum. They had come from the Jaffna peninsula and claimed that they had fled because they had been arrested and beaten by the Sri Lankan army which had been fighting rebels in the north. Authorities could find no evidence to support such claims or even that a war was underway in the north. Without going into our devious method of reaching northern Sri Lanka, we did finally get on a train into the Jaffna peninsula-only to have to get off and board buses after we went through Elephant Pass because the train tracks had been blown up by rebels. After gathering research material that demonstrated a full scale insurgency war was underwayabout which the Canadian ambassador in Colombo had informed us there were extensive rumours but no independent verification since Westerners had been forbidden to travel to the north-our finding appeared in Saturday and Sunday two page spreads in the Toronto Star even before we got back to Canada. The greatest satisfaction was that Canada, within three weeks, reversed its policy on rejecting Tamil refugee claimants from the north. 
I do not want to be blasé about the physical risks of undertaking such research, though I think the only risk we faced in Sri Lanka was a very small one when I was eventually arrested by the army and held for a day in the military camp at Elephant Pass. The greater risk followed when I was the only guest in a ten story hotel south of Elephant Pass where we had to stop because of the curfew, and I was awoken by gunfire to discover a battle raging in the fields outside the hotel but without any idea of who was firing at whom. By the morning all was quiet. I say that we should not be blasé because in what had become the Centre of Refugee Studies that had been awarded a large grant as a centre of excellence one of my graduate students, Andrew Forbes, after whom the resource centre there has been named, was deliberately machine gunned by a hit man on a motorcycle after he emerged from a bar in the late evening in northern Uganda where he had been undertaking research on those displaced by the war between the Lord's Resistance Army and the Museveni's Ugandan government.

However, my subject matter is not physical risk but the difficulties of undertaking objective research on civilian protection during violent conflict, specifically, in this case, the application of just war norms in the conduct of the Gaza war.

\section{Reporting and Media Coverage of the Gaza War}

On 13 May 2009, Libby Davies, the NDP representative for Vancouver East, tabled two petitions in Parliament on alleged Israeli war crimes in Gaza. The first petition was from students at the Stratford Hall International Baccalaureate World School who wanted the Canadian government to actively support a UN war crime investigation on three events presented as historical facts: 1) the 6 January Israeli air strike against the UN school; 2) the strike against the UN headquarters; and 3) the use of white phosphorous in densely populated civilian areas of Gaza. The second petition was from a Toronto group, the Women in Solidarity with Palestine and the International Jewish Anti-Zionist Network; the two organizations wanted to draw attention to the fact that the Canadian government has failed to condemn Israel's clear violation of international law and war crimes in Gaza and wanted the Government of Canada to undertake a change in its position regarding the Middle East immediately and to initiate concrete action to hold Israel accountable for its ongoing violations of international and humanitarian law.

Note that the calls were for investigations not about alleged incidents but about assumed facts. Violations of international law were assumed rather than something to be determined by investigations. Further, the proponents of the investigations were explicitly identified with the Palestinian cause in one instance. There were no calls to investigate alleged assassinations of Fatah members, use of child soldiers, etc., on the other side. On the other hand, it had been very difficult to directly access information since Israel had banned independent observers and journalists from entry into Gaza to cover the war unless, as in the case, for example, of the New York Times, they already had a correspondent based in Gaza. The Foreign Press Association of Israel had denounced the restrictions as an "unprecedented denial of access to Gaza for the world's media" that put "the state of Israel in the company of a handful of regimes around the world which regularly keep journalists from doing their jobs" (Bronner 2009). Thus, although the 27 April 2009 Report in all three of its categories ranked Israel significantly higher than any other Middle Eastern country, as a direct result of the restrictions on journalists in Gaza, Israel's freedom ranking dropped from 59th to 72nd and to "partly free" for the first time because of restrictions on journalists' freedom of movement, 
increased self-censorship and 'biased reporting' during wartime according to Washington-based Freedom House Institute. ${ }^{4}$

Because of limitations of space, and because these were the three most referenced incidents, I will restrict my research to investigating the application of ius in bello norms during the Gaza War to the alleged 6 January Israeli air strike against the UN school, against the UN headquarters and the use of white phosphorous in densely populated civilian areas of Gaza. The last two will be combined since the news reports on 15 January 2009 reported that the UN headquarters was hit by Israeli "white phosphorous" shells (Times Online 2009). Further, as in the recent end to the war against the Tamil Tigers (the LTTE) in Sri Lanka, where similar charges were made about indiscriminate bombarding of the civilian population by government forces and more muted accounts of the LTTE using the civilians as shields, these issues are not confined to Gaza or to the Israeli-Palestinian war but are pervasive in Iraq, Afghanistan, Pakistan and many other locations where wars of insurgency are underway.

\section{Immediate Background to Gaza War}

Israel's unilateral complete withdrawal from Gaza in 2005 had the immediate effect of weakening Fatah, eventually bringing Hamas first to political power in Gaza when Hamas participated in and won the democratic elections to the Palestinian Legislative Council in January 2006 and then to absolute military power when it engaged in a military coup to dislodge Fatah from the Strip altogether. Israel then closed the border crossings given Hamas attacks on Israel and Hamas' rejection of the two-state solution. Israel's blockade was part of the "new" warfare aimed, not at destroying the enemy, but at altering enemy behaviour-to restrict or limit the resupply of military equipment to Hamas controlled Gaza in order to limit rocket attacks on Israel that had increased enormously in 2007 and the first half of 2008. As such, the blockade was legal. ${ }^{5}$

Without resolving the linked issues of reopening the Rafah crossing to Egypt or the release of Gilad Shalit, the Israeli soldier held captive by Hamas, on 18 June 2008, the "Calmness Agreement" mediated by Egypt between Israel and Hamas entered into force. Hamas agreed to stop firing rockets into Israel for six months. In return, Israel agreed to cease its targeted attacks against the leaders, fighters and officers of Hamas and to open the crossings gradually to increase the non-military supplies into Gaza. Rocket attacks did stop. Israel did permit a $10 \%$ increase in the number of trucks into Gaza while retaining control of the type and quantities of goods. Increased amounts of gas were permitted for entry for Ramadan which began on 1 September 2008. Both parties gained initially from the agreement since the Olmert government was subject to mounting criticisms for not responding with full military force to the rocket attack and Hamas used the time to rebuild

\footnotetext{
${ }^{4}$ When Israel withdrew from Gaza in 2006, "Israel's civil liberties ratings improved from 3 to 2 due to a marked decrease in terrorist attacks in 2005, as well as a surge of civic activism surrounding the country's 'disengagement' from the Gaza Strip." Freedom House, "Freedom in the World - Israel (2006)." http:// www.freedomhouse.org/inc/content/pubs/fiw/inc_country_detail.cfm?year=2006\&country=6985\&pf. The Report went on to note: "Press freedom is respected in Israel, and the country features a vibrant and independent media landscape... While newspaper and magazine articles on security matters are subject to a military censor, the scope of permissible reporting is wide and there is a broad range of published material... the independent judiciary and an active civil society adequately protect the free media."

${ }^{5}$ For an argument on why the restrictions were not illegal, see Weiner and Bell 2008 and for a refutation of Amnesty International's claim, see "Amnesty International's anti-Israel stance undermines human rights and international law," Prof. Avi Bell, Jurist Hotline Blog, January 5, 2009
} 
its domestic support and regain its composure without its leaders, fighters and centres being under constant attack.

Since the cease fire was really not directed towards peace but simply offered a respite to both sides, it was doomed to failure. Well before the six months came up, the cease fire began to crumble. Hamas continued to smuggle military supplies through the tunnels to Egypt. However, the precipitating cause on 4 November was an IDF military exercise to destroy a tunnel under construction from Gaza in the so-called no-man's zone that Israel interpreted as part of a plan to capture more Israeli soldiers. Hamas responded with a barrage of rockets on towns in southern Israel. The ceasefire was effectively over and the world watched to see how much the conflict would escalate.

\section{Ethics and the Law}

In the conduct of war, two ethical issues stand out. Was the response by Israel proportionate to the provocations? In the next section on numbers, I will deal with how that issue was and could be researched. The second question is whether civilians were adequately protected; was sufficient caution taken to ensure a differentiation between targeting fighters and civilians? That is, not only should civilians not be directly attacked, but in accomplishing military objectives, reasonable consideration of civilian protection must be undertaken. This is the major issue that will be discussed in reference to the alleged attack on a UN school and the attack on the UN headquarters. Thirdly, were inappropriate weapons used or were legal weapons used in inappropriate ways during a military engagement? The last issued will be taken up in the discussion of assessments made regarding the use of phosphorus.

First, I must clarify the rules applicable to both international law and ethics to ensure respect for human beings and the legitimate use of arms for military purposes. The rules are the same except that under international law, an individual or a group or an institution is only guilty of a war crime if charged and found guilty before an appropriate war crimes tribunal in accord with the legal rules of evidence and due process. There are three applicable rules. The first is the norm of proportionality dictating the amount of force that is ethically appropriate to achieve a military objective (Walzer 1997). The second is the principle of discrimination that dictates the appropriate measures to be taken in protecting civilians and targeting military combatants based on the premise that individuals have standing deserving of respect and independent of the exigencies of war so that a distinction must be made between how militants can be attacked as distinct from civilians. ${ }^{6}$ From the latter, as either a sub-principle or a derivative principle, inappropriate weapons cannot be utilized either at all or in some circumstances.

\section{Numbers}

I have already mentioned the propensity to exaggerate numbers of refugees, of internally displaced and of deaths. This seems to be a constant in all conflict situations independent of any effort to demonize Israel or to pull at heart strings in favour of civilians and/or the militants being attacked. In the very recent Sri Lankan war that just ended, the repeated claim at the beginning was that a half million civilians were trapped between the advancing

${ }^{6}$ Ibid, 41. 
Sri Lankan army as the perimeter protected by the retreating LTTE forces shrunk. By the end, in counting the numbers displaced in camps and those killed (an estimated 7,000), the numbers appeared to be about $40 \%$ of previously widely reported figures. ${ }^{7}$

Further, this seems to be the case no matter how many times the exaggerations are exposed. For example, in Operation Defensive Shield in Jenin, immediate reports indicated 1,500 deaths, subsequently lowered to "hundreds". Following an independent inquiry, the number was established as $54^{8}$ and 45 were militants. ${ }^{9}$ This suggests not only that the numbers of civilians killed by Israelis was grossly exaggerated but so was the charge that Palestinian militants used innocent civilians as human shields. None of these inaccuracies excuse the horrific treatment accorded the civilians in the camp by the IDF, including wanton destruction of property and use of civilians as shields. However, I shall try to show that this exaggeration by Palestinians did not recur in the case of Gaza

The Gaza-based Palestinian Center for Human Rights (PCHR) reported that 1417 Gazans had been killed of whom 926 were civilians, including 313 children and 116 women; 491 were combatants (236) and police officers $(255){ }^{10}$ though PCHR, under orders from Hamas, deliberately excluded the name of some militants who were killed. ${ }^{11}$ But this would only have increased the numbers reported as killed without accounting for the real discrepancies with Israeli official counts. The IDF reported that of 1,166 killed, 709 were Hamas militants, 295 were civilians (including 89 minors and 49 women) and 162 men who could not be definitively classified as militants or civilians. While Israel classified the police as combatants, the Palestinians classified the 255 as "non-combatant" police officers killed at the outset of the war. One debate over the number of militants killed is a debate over classification.

What are the other debates over numbers?

Differences in Counts

\begin{tabular}{lllllllll}
\hline & & Non-Civilians & & & Civilians & & Total \\
Side & Total & Police & Combatants & & Men & Women & Children & \\
Pal & 1417 & 255 & 236 & & 497 & 116 & 313 & 926 \\
IDF & 1166 & 255 & 454 & 709 & $157+162=319$ & 49 & 89 & 457 \\
Diff & 251 & 0 & 218 & & 178 & 67 & 224 & 469 \\
\hline
\end{tabular}

In the debate over the numbers of civilians killed, if we bracket the police officers, one difference is in the classification of male deaths. The difference between the number of classified and unclassified male civilian deaths according to the IDF (319) and the numbers

\footnotetext{
${ }^{7}$ Rather than 500,000, Sri Lanka's displaced numbered just over 192000. OCHA, 7 May 2009.

8 The numbers reported by more detached reports at the time varied between 52 and 66 .

${ }^{9}$ Kofi Annan appointed 12 members to the Jenin Inquiry from a wide variety of countries. The Report by the Jenin Inquiry Regarding the Israel invasion of the Jenin Refugee Camp from 3-18 April 2002 (Brian Woods and Ray MacMillan eds.) [http://www.jenininquiry.org/Jenin\%20Inquiry\%20Report.pdf]

${ }^{10}$ Palestinian Centre for Human Rights http://www.pchrgaza.org/files/W report/English/2008/22-01-2009. htm

${ }^{11}$ These include Abu Zakaria al-Jamal (3.01.09), Mahmoud Shalpokh and Muhammad Hilou (4.01.09), Muhammad Farid Abdallah, Muhammad Abdallah Obeid and lyad Hassan Obeid (5.01.09), Ayman Siam (6.01.09), Abdul Karim Rafeeq Hassan and Bilal 'Abdul Hadi 'Ali (7.01.09) Amir Mansi (10.01.09), Abu Muhammad al-Marri (13.01.09) but Said Mamoud al-'Emari was recorded as killed on 12.01.09 (perhaps the same person) whose deaths had previously been reported as combatant deaths somewhere on the dates indicated. Cf. CAMERA (Committee for Accuracy in Middle East Reporting, Media Analysis، 23 May 2009. http://www.camera.org/index.asp?x_context=2\&x_outlet=118\&x_article=1603.
} 
according to the PCHR (497) is 176 which is not much less than the 218 non-civilians classified as combatants by the Israelis but as non-combatants by the PCHR. This suggests that in addition to how the police officers are classified, there is a difference of about 200 in how individual males who died were classified. But there is also a difference of 251 in the number of total deaths which is approximately the number of additional children that the PCHR classified as killed compared to the numbers counted by the Israelis.

So there are three major discrepancies in the counts:

\& The way to classify the police officers killed

\& Whether to classify about 200 males killed as combatants or not

\& How many children were killed and, therefore, the total number killed.

We begin with the issue of the police killed.

The Israeli shock and awe attack on 19 December 2008 began with a bombardment of a graduation ceremony in a police academy.

On the first day of Operation Cast Lead, the air force bombed the graduation ceremony of a police course, killing dozens of policemen. Months earlier, an operational and legal controversy was already swirling around the planned attack. According to a military source who was involved in the planning, bombing the site of the ceremony was authorized with no difficulty, but questions were raised about the intent to strike at the graduates of the course. Military Intelligence, convinced the attack was justified, pressed for its implementation. Representatives of the international law division (ILD) in the Military Advocate General's Office at first objected, fearing a possible violation of international law. ${ }^{12}$

The IDF was clearly aware of the issue of intent both as an ethical and a legal issue in assessing actions in the conduct of war. Secondly, at least initially, there was a difference of opinion between the military strategists and the representatives of the IDF international law division (ILD). ${ }^{13}$ Third, the strike only went ahead when the ILD authorized it. On the substantive level, one issue of debate was how come on one day, people who are civilians, on the next day are considered military simply by participating in a graduation ceremony to

\footnotetext{
${ }^{12}$ Feldman and Blau 2009. The evidence for the police being involved with the security forces fall into two categories:
}

a) Pre-vetting: to prevent terrorists from being recruited into the police force, the Palestinian police, in accordance with the Oslo Accords and the Palestinian Police Act, were to be selected in cooperation with Israeli security forces (Annex I, Article II, Oslo Accords, but Hamas (following in the footsteps of the PA) did not submit a list of all potential police recruits to Israel for approval (Annex I, Article IV (4)) Not only has Israel been denied pre-vetting rights, but known terrorists were recruited into the police force;

b) Instead of 9,000 police permitted under the Gaza-Jericho accord of May 1994 (Annex I, Article III (3)), first 20,000 and then 24,000 (Oslo II, Annex I, Article IV (3)) were deployed; that figure has been exceeded by at least 10,000 and perhaps 26,000 . Reports suggest that the Palestinian security forces may exceed 50,000 men.

\footnotetext{
${ }^{13}$ There is no connection between the ILD sanctioning an action and such an action being both legal and ethical. Further, it certainly does not mean that the ILD was "objective"; the ILD may be more militant and pro-IDF than comparable civilian bodies, either because of internal pressures or simply the cultural atmosphere and the imperatives of war to provide the tools to allow the army to operate legally as a restraint without impeding its effectiveness. Finally, the ILD operates within a human personal context with a different role when the head of the ILD is the more reticent Colonel Pnina Sharvit-Baruch (in contrast to his predecessor, the renowned and widely respected Daniel Reisner) and the head of Southern Command in charge of Operation Cast Lead is General Yoav Gallant with a reputation as a cowboy indifferent to legal niceties.
} 
convert them to police officers. Hegel defined police as part of civil society because their mandate was "to serve and protect" civilians not to attack enemy soldiers. However, the ILD evidently determined that police were part of Hamas' security forces and, therefore, part of the armed forces. According to the news report, the ILD concluded that these police graduates were not perceived as police "but the equivalent of the army, just as in the face of the enemy's army every soldier is a legitimate target." Prof. Yuval Shany, a professor of public international law at the Hebrew University of Jerusalem, claimed that although in international law attacking police is prohibited by international law, Hamas uses police in combat roles and therefore the distinction becomes moot. ${ }^{14}$

Though Palestinian and pro-Palestinian human rights and humanitarian organizations denounced the Israeli action as a war crime based on indications of "a malicious intent to inflict as many casualties as possible, with many of the police stations located in civilian population centers, ${ }^{15}$ there was no parallel outcry when a suicide bomber in a police uniform detonated his explosives inside a police training centre in southern Afghanistan on Monday, 3 February 2009 killing 21 officers and wounding at least 20, an action for which the Taliban claimed responsibility, or the attack on the Lahore police station in Pakistan on 27 May 2009 when 60 were killed. ${ }^{16}$ I could find no effort to try or indict the Taliban for war crimes. So how does a researcher classify police in a context of asymmetrical warfare where police play an ambiguous role? The answer was not even self-evident for the IDF.

Quite aside from including all coincidental deaths and deaths by retribution of Hamas against Fatah members, there is the issue of whether to classify a dead male as a militant or a civilian. I do not know how this can be definitively determined by either side given that, in asymmetrical warfare, "Hamas militants are fighting in civilian clothes" as Steven Erlanger in The New York Times reported, but that should have been unsurprising (Erlanger 2009a). However, the PCHR did provide the names of each and every one of the dead. This permitted the IDF to challenge many of their classifications. Thus, "Tawfiq Ja'abari, the commander of the Hamas police, and Mohammed Shakshak, a personal assistant to the head of Hamas' military wing, Ahmed Ja'abari, are both described as dead children on the Palestinian list (Harel 2009b)." According to CAMERA, the Committee for Accuracy in Middle East Reporting in America, in its Media Analysis dated 23 May 2009, the following militants were listed as civilians:

\& Jihad Abu Medif (Medyiff)—identified as member of Al-Aksa Martyrs Brigade

\& Haitham Abu al-Qumsan-identified as member of Al Aksa Martyrs Brigades

\& Hamdi Fareed Abu Hamada-identified as member of Al Aksa Martyrs Brigades

\& Eyad al-Maqqousi-identified as member of Al Aksa Martyrs Brigades

\& Mohammed 'Abed Hassan Brbakh-identified as DFLP commander

\& Tariq Nimer Abu Amsha_identified as member of Islamic Jihad al-Quds Brigades

\& Shams Omar-Al-Quds (Islamic Jihad) commander in Gaza.

\footnotetext{
${ }_{14}$ Yuval Shany has a record of being strict in the interpretation of international law in the conduct of war since, in the same interview, he claimed that IDF targeting of Hamas ministry buildings unrelated to the military "that do not serve a military purpose is a violation of the rules of war. The buildings are civilian sites and must not be attacked" but the ILD countered that since Hamas is categorized as a terrorist organization, the entire governmental infrastructure serves terrorist principles and is not immune from being targeted presumably on the basis of the logic that any form of governance under the control of terrorists is a legitimate target not because it serves terrorist purposes, but because they contribute to the support of the terrorist organization.

15 The Electronic Intifadah, http:/electronicintifada.net/bytopic/687.shtml

${ }^{16}$ Cf. Khan 2009; for the attack in Pakistan, see: www.foxnews.com/story/0,2933,522518,00.html.
} 
Given the careful recording by the PCHR, the listings include whether the young men (most were between the ages of 16 and 40) were killed with other young men (the vast majority) or with women and/or children (a few), but this is just as much an indicator of Palestinian social life as of militant involvement. A more significant indication is that while males in the age range of $16+$ constitute $25 \%$ of the Palestinian population, they make up $74 \%$ of the civilian fatalities. It is possible that the PCHR may have misclassified a number of the militants as civilians.

What about the discrepancy in the number of children killed? The discrepancy in children killed arise over the age definition since 15-17 year olds are often part of militant groups and, in any case, a disproportionate number of children in that age group were killed, This suggests that a small number of children may, in fact, have been militants. But this explanation is small relative to the large discrepancy in the totals.

However, except for the discrepancies in children's deaths, these counting issues are not as discordant as many have made them out to be. The real issue is whether the number of civilian deaths was disproportionate to the military aims. They were certainly disproportionate to the number of Israelis killed-9 soldiers and 4 civilians. However, it is not a war crime to suffer few casualties while the enemy suffers multiple more. The war crime charge is relevant if the civilians killed were a product of indiscriminate action. "The excessively disproportionate civilian death toll, and Israel's conduct of hostilities, including indiscriminate attacks, willful (sic!) killing, the extensive destruction of property, target selection, the lack of precautions taken in attack, the excessive use of force, and the use of weapons such as white phosphorous in civilian areasdemand effective judicial redress." (PCHR Report) This was not a charge that only the Palestinians made. Propelled by a number of embarrassing reports by returning Israeli soldiers about the mis-behaviour of their buddies-in-arms, Israel's leading newspaper, $\mathrm{Ha}^{\prime}$ aretz, levelled the same charge:

The questions are plentiful and troubling: the mass killing of civilians, among them 300 children $^{17}$ and 100 women; the shooting at medical crews; the use of illegal munitions against a civilian population, including white phosphorus shells; the prevention of the evacuation of wounded; bombing and shelling of schools, hospitals, supply convoys and a UN facility. These questions cannot remain unanswered. The suspicion that Israel committed war crimes in Gaza is liable to cause it great damage. This is precisely the moment at which Israel needs to pre-empt the others and investigate itself. $^{18}$

\footnotetext{
${ }^{17}$ UNICEF's Executive Director, Ann M. Veneman, used the same figure of 300 child deaths on 14 January 2009. http://www.unicef.org/turkey/pc/ep26.html "Over 300 children have been killed and more than 1,500 wounded, since the beginning of the Gaza crisis on 27 December, 2008." No evidential support was provided to back up the claim though it was repeatedly broadcast in the Israeli media, on al Jazeera television and abroad. Further, UNICEF has a stellar reputation.

${ }^{18} \mathrm{Ha}$ aretz, editorial, "Investigate Now," 1 February 2009. http:/middleeast.about.com/gi/dynamic/offsite.htm? $\mathrm{zi}=1 / \mathrm{XJ} \& \mathrm{sdn}=$ middleeast $\& \mathrm{cdn}=$ newsissues $\& \mathrm{tm}=876 \& \mathrm{gps}=27 \_769 \_1102 \_640 \& \mathrm{f}=00 \& \mathrm{tt}=2 \& \mathrm{bt}=1 \& \mathrm{bts}=1$ \& zu=http\%3A/www.haaretz.com/hasen/objects/pages/PrintArticleEn.jhtml\%3FitemNo\%3D1057672
} 
The question of the discrepancy between the number of child deaths recorded by the PCHR and the IDF, I suspect, can be traced to three factors:

\& The age bracket for classification as a child

\& The number of older children actually targeted by Israeli munitions ${ }^{19}$

\& The number of children who died as part of the normal death toll, certainly exacerbated as a result of the war

The real questions, however, do not hinge on numbers but on targeting civilians deliberately or indiscriminately, which carries us to our next issue.

\section{The Alleged 6 January Israeli Air Strike Against the UN School}

Since civilians are never permissible targets of war, it follows that schools should be immune from attack even though civilian deaths may sometimes be unavoidable and then referred to, however inappropriately, as "collateral damage". The principle of double effect justifies civilian deaths when their deaths are unintended, indirect and accidental and the result of a legitimate military exercise. If those civilian deaths were foreseeable, the issue is the extent to which care was taken to avoid those deaths and the significance and importance of the military target at the time that risked the lives of those civilians knowingly.

In a widely reported episode, on the 6 January 2009, three mortars from the IDF allegedly killed 43 civilians in the Jabalya refugee camp in Gaza after they had taken refuge

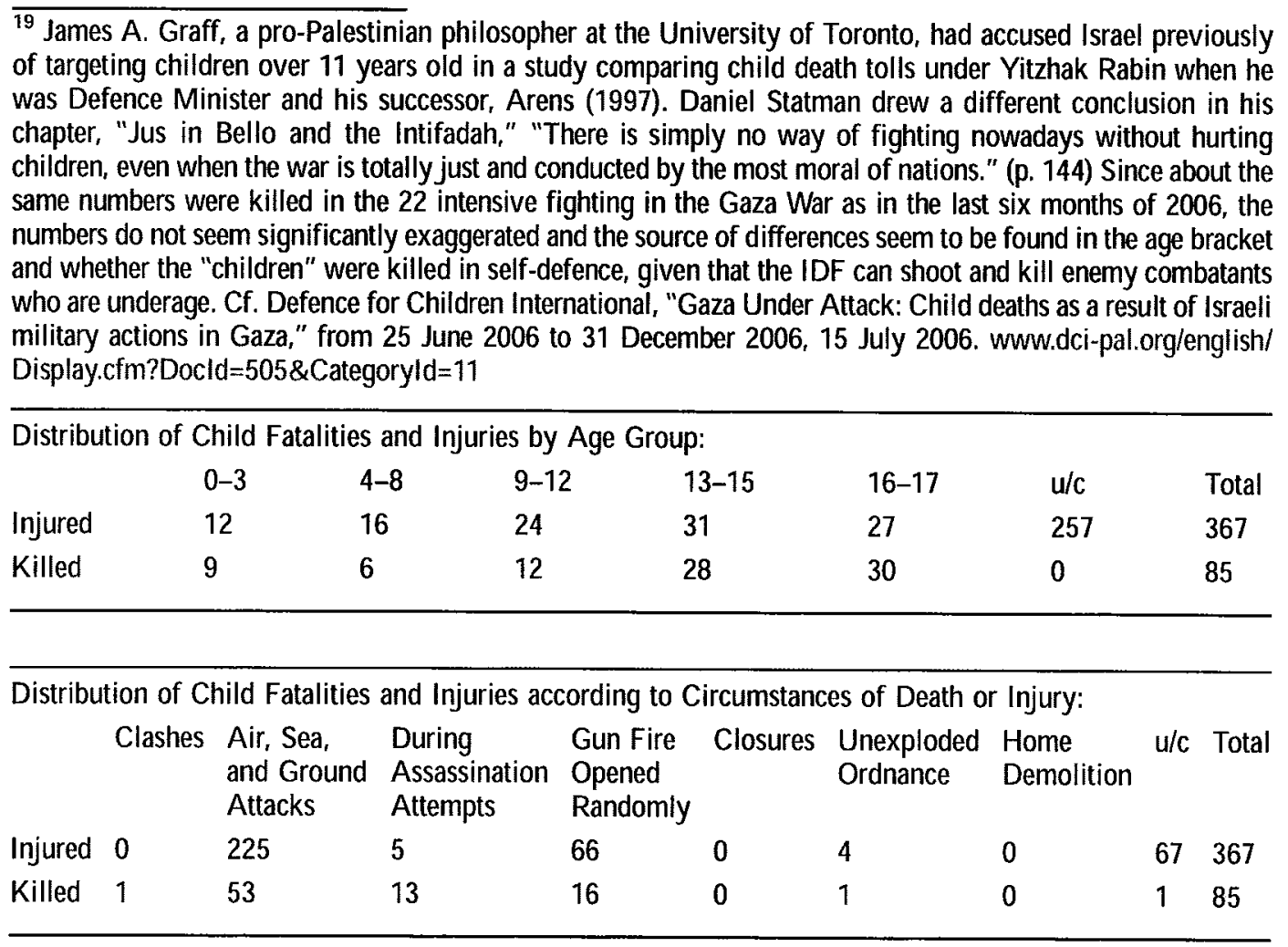


inside UNRWA's Ibn Rushd Preparatory School for Boys. ${ }^{20}$ Subsequently, the United Nations corrected its original report and said the civilians were killed on the street beside the school.

"Hundreds of Palestinians had fled their homes for the refuge of the al-Fakhoura school, hoping the blue and white flag of the UN flying over the impromptu shelter would protect them from the Israeli onslaught. The UN had even given the Israeli army the co-ordinates for the building to spare it from the shells and air strikes raining down on the Gaza strip. But yesterday afternoon tank shells exploded outside the school, sending shrapnel into the crowds, killing at least 40 and wounding another 55 . It was the worst confirmed bloodshed of Israel's attack on Gaza and sparked outrage and condemnation around the globe, with the US President-elect Barack Obama breaking his 11-day silence, the UN Secretary Ban Ki-moon calling the incident "totally unacceptable" and Gordon Brown describing the conflict as "the darkest moment yet for the Middle East". ${ }^{21}$

UN Secretary-General Ban Ki-moon in a "harsh and grim" report to the Security Council demanded a thorough investigation by Israel of "several incidents of outrageous attacks against UN facilities." 22 This was not the only claim of IDF artillery hitting a school. Adnan Abu Hasna, a spokesman for the UN Relief and Works Agency (UNRWA), said two brothers had been killed and 14 people had been wounded, including the boys' mother, when Israeli tank fire hit the school run by UNRWA in the northern town of Beit Lahiya. Palestinian medics had earlier put the death toll at six. A United Nations official called for an investigation into possible war crimes. Reports said that the school had been crowded with 1,600 people who had sought shelter from Israel's three-week offensive in Gaza.

With respect to the first incident, subsequent investigations established the following:

\& UNRWA provided the IDP map coordinates of all its schools, and buildings

\& The IDF initially claimed that they were simply returning fire that had been coming from the compound, thereby implicitly accepting the claim that they had hit the compound

\& The IDF subsequently withdrew both the claim that they had responded to fire from the compound by claiming that the militants had launched two missiles from a yard adjacent to the building, and their acceptance of the fact that their shells had hit the

\footnotetext{
${ }^{20}$ This was one of the incidents that launched a new wave of lawfare initiatives. Ibrahim Barzak and Steve Weizman, "Israel shells near UN school, killing at least 30," "Despite pressure and outrage from the international community, Zionist authorities in Israel are refusing to cooperate with prosecutors in the case of war crimes by refusing the public release of names and photographs of Israeli soldiers and commanders guilty of committing atrocities in the field, according to a wire from the Fars News Agency. The ZionistIsraeli government has, however, tried to mitigate responsibility for the heinous crimes against the Palestinian people to a few high-ranking military officials who have already been exposed. Iranian Press TV reported the ban applies to officers of the rank of battalion commander and down, and also prohibits the publication of information linking particular commanders to certain areas in Gaza that suffered heavy losses. Reports from Israeli and Dutch press indicate proceedings against one Zionist-Israeli brigade commander are underway in a Dutch court, a likely development responsible for the Zionist government in censoring those culpable for the war in Gaza." 6 January 2009, AP News.

http://freemediaproductions.newsvine.com/_news/2009/01/27/2359861-israel-tries-to-cover-tracks-amidwar-crimes-allegations?threadld $=482714$

${ }^{21}$ Macintyre and Sengupta 2009. See also Hider and Sugden 2009

${ }^{22}$ Security Council Report, 21.01.09. Palestinian representative Riyad Mansour, said he was satisfied with Ban's comments because in his view "determining the next step...includes many things, including legal proceedings in (the) international legal system." Cf. Shamir 2009.
} 
school that fell within the 30 yard error range of the mortars, then once again reversed positions and reinstated its original claim, ignoring Hanan Abu Khajib's testimony "that Hamas fired just outside the school compound, probably from the secluded courtyard of a house across the street, 25 yards from the school" 23

\& No one was killed inside the school or even within the compound grounds, though 12 were injured from flying shrapnel.

\& On 2 February 2009, UNRWA corrected the record and issued a statement that the UN "would like to clarify that the shelling and all of the fatalities took place outside and not inside the school (Harel 2009c)."

\& UN-OCHA did not correct its claim that the people were killed inside the school long after this claim had been disproven. ${ }^{24}$

\& 41 were killed on the street outside, including 3 school children then out on the street, though the IDF still disputes that figure as too high; however, very few reports noted that two Hamas militants were included in the dead.

However, a large number of civilians were hit, and the question remains whether that collateral damage was too great just to kill the two men firing the missiles. On the other hand, why did the reports not condemn Hamas for using innocent civilians as shields when firing missiles from locations crowded with civilians?

\section{UNRWA Headquarters and Phosphorus}

What about the UNRWA vocational training centre and headquarters in Gaza City? Hundreds of Gazans had sought shelter there and three people were wounded in the barrage. According to John Ging, head of Gaza operations for the UN Relief and Works Agency, the UN compound, comprising workshops and warehouses as well as offices, was struck about a half-dozen times over a roughly two-hour period while more than 700 civilians were sheltering there. UK's Prime Minister, Gordon Brown, called the shelling of the UN compound as "indefensible" and "unacceptable". "The UN's mission in Gaza is purely humanitarian, bringing relief to civilians suffering in appalling conditions as a result of the ongoing military action and restrictions on food and medical supplies entering Gaza," (Adetunji et al. 2009) Even U.S. Secretary of State Condoleezza Rice issued a warning to Defense Minister Ehud Barak and Foreign Ministers Tzipi Livni in the aftermath of this incident.

In other attacks against UN facilities, the IDF was accused of killing civilians. Matthew Fisher reported in The National Post (10 January 2009) that two UN truck drivers were killed by what UN officials claimed was an Israeli tank attack. This report was later corrected when, first, it was established that only one driver was killed and then, afterwards, when the UN officials admitted they could not be sure of the origin of the firing. The IDF all along denied responsibility and an IDF medic demonstrated that the driver had been killed by gunshot wounds, not shrapnel. Regarding the alleged attack on a UNRWA vehicle

\footnotetext{
${ }^{23}$ Erlanger, ibid. Note that Hamas even sheltering beside a school to fire a rocket and thereby risk the lives of civilians could potentially be a war crime.

${ }^{24}$ The UN's Office for the Co-ordination of Humanitarian Affairs in "its more comprehensive weekly report, published three days later, stated that "Israeli shelling directly hit two UNRWA schools ...", Martin 2009. Cf. Un OCHA, "Situation report on the humanitarian situation in the Gaza Strip No.18 ... 27-28 January 2009. The document contains no correction of its earlier claims. http://www.reliefweb.int/rw/rwb.nsf/db900SID/ MYAI-7NR5GD?OpenDocument
} 
in Tel El Hawa, an IDF investigation concluded that the vehicle did not bear UN markings and contained a Palestinian anti-tank squad. In one incident, in which a soldier was found to have fired at a UN vehicle in breach of the IDF's rules of engagement, the soldier in question was court-martialed. ${ }^{25}$ The IDF claimed that it had not, at any time, fired with the deliberate intention to hit a UN vehicle or facility in any of the 13 incidents investigated. So the first casualty of the fog of war is often the facts. But the critical issue of intention in ius bello is to determine whether the party that killed civilians or risked the lives of civilians in a retaliatory attack properly weighed the military benefits against the potential of civilian harm (proportionality) and took the necessary steps to avoid collateral damage. Two issues are at stake-the facts and the norms. Did the attack take place as described? Were the key ius in bello norms observed?

If immediate responses from the UN or international agencies could not be relied upon, neither could the immediate responses from Israel. An IDF knee-jerk response would simply declare that Hamas militants of staging attacks from schools, mosques and other civilian areas. Thus, on the second last day of the 22-day war, an official military statement noted that the targets bombed not only included smuggling tunnels along the Egyptian border and a rocket launcher ready for firing, but also a mosque used to store arms that also housed a tunnel entrance.

What justification was used for the attack on the UN headquarters? A UN Board of Inquiry recommended an impartial investigation into Gaza war violations and Appointed Justice Richard Goldstone with an impeccable reputation to conduct the inquiry. ${ }^{26}$ The UN Board of Inquiry on its own into incidents involving attacks on UN installations and personnel from 27 December 2008 to 18 January 2009, including the United Nations Relief and Works Agency's (UNRWA) Jabalia and Beit Lahiya schools, the UNRWA headquarters and nearby Gaza Training Center as well as the headquarters compound. It found the IDF responsible for casualties and damages in seven of the nine incidents investigated, but found that a Palestinian rocket was the cause of damage in one incident and could not draw a conclusion in the ninth case. The Israeli Foreign Affairs Ministry responded by calling the Report "tendentious, patently biased, and ignore[d] the facts presented." The real question, however, was not just whether the IDF shells struck, but whether they contained 'white phosphorous,' and under what circumstances the shells were fired. ${ }^{27}$

The use of 'white phosphorous' is not in itself illegal. The Geneva Convention of 1980 proscribes the use of white phosphorus as a weapon of war in civilian areas, although it can be used to create a smokescreen. The Israel Defence Forces (IDF) claimed that all weapons used in Gaza were "within the scope of international law". Peter Herby, head of the International Committee of the Red Cross (ICRC) Arms Unit, stated:

The use of weapons containing white phosphorous is, like the use of any other weapon, regulated by the basic rules of international humanitarian law. These require parties to a conflict to discriminate between military objectives on the one hand and civilians and civilian objects on the other. The law also requires that they take all

\footnotetext{
${ }^{25}$ Col. Itzik Turgeman, IDF Investigation Report 22 April 2009. http://www.jewishvirtuallibrary.org/jsource/ Peace/IDFrelease042209.html

${ }^{26}$ Human Rights Tribune, "Richard Goldstone to lead Human Rights Council fact-finding mission on Haza conflict," 3 April 2009. http://www.humanrights-geneva.info/Richard-Goldstone-to-lead-Human,4309

27 The $120 \mathrm{~mm}$ shells, a recent acquisition, have a computerized targeting system attached to a GPS. Brigade commanders say they were very effective, but they were also responsible for two very serious mishaps: a strike adjacent to a UNRWA school that killed 42 Palestinians and a friendly fire incident that seriously wounded two officers.
} 
feasible precautions to prevent harm to civilians and civilian objects that can result from military operations. Attacks which cause "disproportionate" damage to civilians and to civilian objects are prohibited. Using white phosphorous as an incendiary weapon, i.e. to set fire to military targets, is subject to further restrictions. The use of such white phosphorous weapons against any military objective within concentrations of civilians is prohibited unless the military objective is clearly separated from the civilians. The use of air-dropped incendiary weapons against military objectives within a concentration of civilians is simply prohibited. These prohibitions are contained in Protocol III of the Convention on Certain Conventional Weapons. ${ }^{28}$

The ICRC went further and issued a statement that there was no evidence that Israel used "phosphorus in a questionable way, such as burning down buildings or consciously putting civilians at risk.," even though ICRC rarely issues such statements but discusses alleged breaches of war crimes with the combatant nation. In fact, ICRC not only said that the use of phosphorous was not illegal, but also did, say-unusual for ICRC - that, "We have no evidence to suggest it's being used in any other way," than to light the battle field. ${ }^{29}$

The most damaging report was one issued by Human Rights Watch that accused Israel of using white-phosphorus munitions during its offensive in the Gaza Strip and, in particular, against the UNRWA headquarters as well as on 9-10 January near the city of Gaza and the Jabalya refugee camp. Human Rights Watch had for years campaigned to ban the use of such weapons altogether because of the severe burns they caused. According to the IDF, 200 phosphorus shells were fired from mortars, 180 targeting orchards where gunmen had hidden after launching rockets. Evidently, a reserve paratroop unit did explode about 20 shells in a built-up area of northern Gaza (Beaumont 2009). The IDF's Col. Shai Alkalai investigated the matter focusing on the use of phosphorus shells, either $81 \mathrm{~mm}$ or $120 \mathrm{~mm}$, fired from mortar guns. The one problematic incident was the reserve paratroops brigade that fired about 20 such shells in a built-up area of Beit Lahiya. TimesOnline reported that, "The Israeli military has denied using white phosphorus shells in the Gaza offensive, although an investigation by The Times has revealed that dozens of Palestinians in Gaza have sustained serious injuries from the substance, which burns at extremely high temperatures (Times Online 2009)."

Many international organizations say phosphorus shells should not be used in heavily populated areas. The brigade's officers, however, say the shells were fired only at places that had been positively identified as sources of enemy fire. Finally, the IDF insisted that the use of white phosphorus had been stopped on 7 January whereas the UN compound was hit a week later (Alkalai 2009).

Talk about the fog of war!

\footnotetext{
${ }_{28}$ ICRC, http://www.icrc.org/Web/Eng/siteeng0.nsf/html/weapons-interview-170109; see Gerald Steinberg claimed in a column ("Human Rights Watch: White (Phosphorous) Lies," The Jerusalem Post, 17 January 2009: http://www.spme.net/cgi-bin/articles.cgi?lD=4957)

${ }^{29}$ Op. cit.
} 


\section{Conclusion}

In the popular mind, just war theory is not perceived as the ratio of death and damage suffered relative to military goals, that is, the effort to minimize the harm done to noncombatants against the war aim of prevailing and accomplishing military objectives. In ordinary discourse, proportionality is considered as the ratio of death and damage suffered by one side compared to the casualties and physical damage absorbed by the other side. ${ }^{30}$ The latter is not the conception of proportionality in just war theory. If those were the terms of reference, Israel suffered negligible physical damage, lost 9 soldiers, four from friendly fire, and 4 civilians. In contrast, Gazans allegedly suffered about 1,300-1,400 dead, of whom, according to the IDF, less than one-third were civilian, ${ }^{31}$ but, according to Hamas, $43 \%$ were women and children. ${ }^{32}$

\footnotetext{
30 This popular view is widely shared by the media. Cf. Damstädt and Schult 2009. They stated that "the immense (my italics) number of civilian casualties suggest that it did." But they neither checked their numbers nor the applicable laws and ethical norm - whether, in their own words, the number of deaths was "blatantly disproportionate to the military value of the operation." $h$ ttp://www.spiegel.de/international/world/0,1518,603508,00.html

${ }^{31}$ This figure seems odd since after the first week of the war, the IDF claimed it had killed approximately 300 Hamas out of almost 800 casualties so that civilians would have represented $62.5 \%$ not $33 \%$ of the casualties. Cf. Harel 2009a. See also the claim by an Italian journalist that a Gaza doctor insisted that there were at most 600 casualties, mostly Hamas youth. http://www.ynetnews.com/articles/0,7340,L-3660423,00. html. Certainly CAMERA, the Committee for Accuracy in Middle East Reporting in America, has questioned the Palestinian Committee on Human Rights (PCHR's) figures (16 January 2009). On the other hand, "CAMERA identified a number of Hamas fighters and members of other Palestinian terrorist groups who were either misclassified by PCHR as civilians, not identified as combatants, or omitted entirely from their tabulations." Further, "An analysis of the fatalities by age and gender shows that the majority of civilian fatalities recorded by PCHR are males between 15 and 40 years old, the same age profile as the combatants." http://www.camera.org/index.asp?x_context=2\&x_outlet=118\&x_article=1603) One complicating factor in the counting is that Hamas fighters wore civilian clothing, so the figures of women and children killed are very relevant. So is the independence of the compiler of the figures and PCHR has been explicitly partisan. Further, PCHR allegedly omitted from its casualty figures Hamas members who were widely reported as killed, possibly because Hamas ordered such information to be repressed:
}

- Jihad Abu Medif (Medyiff)-identified as member of Al-Aksa Martyrs Brigade

- Haitham Abu al-Qumsan-identified as member of Al Aksa Martyrs Brigades

- Hamdi Fareed Abu Hamada-identified as member of Al Aksa Martyrs Brigades

- Eyad al-Maqqousi-identified as member of Al Aksa Martyrs Brigades

- Mohammed 'Abed Hassan Brbakh—identified as DFLP commander

- Tariq Nimer Abu Amsha-identified as member of Islamic Jihad al-Quds Brigades

- Shams Omar-AI-Quds (Islamic Jihad) commander in Gaza

CAMERA's examination of PCHR's reports found no mention of several senior commanders from Hamas whose deaths were widely reported in the media:

- Mahmoud Shalpokh on Jan. 4

- Ayman Siam on Jan. 6

- Amir Mansi on Jan. 10

- Muhammad Hilou on Jan. 4 (a man with a similar name was listed but with no indication that he was a member of Hamas or a combatant)

- Abu Zakaria al-Jamal on Jan.3

${ }^{32}$ Erlanger 2009b. Cf. Palestinian Centre for Human Rights, posting, 22 January 2009. http://www.pchrgaza. org/ Note the discrepancy that CAMERA pointed out that of the PCHR child fatalities $23 \%$ are $15-17$ years of age even though this age group constitutes only $8 \%$ of the Palestinian Gaza population. The Palestinian National health Authority figures were even higher reporting 410 "children" dead compared to a figure of 281 for PCHR and only 81 women compared to the PCHR figure of 111. in any case, why were four times as many "children" killed as women when some of the women were fighters? 
Thus, in contrast to other conflicts, the issue in Gaza was not grossly exaggerated figures but rather the understanding of the meaning of proportionality in legal and ethical just war theory, the classification of those killed and the methods for making the classification. There is also the issue of the totally disproportionate response to Israeli actions compared to the actions of others in other conflict areas and to the actions of Hamas or the Taliban elsewhere. For example, one searches in vain for reports of outrage at Hamas' attacks on civilians for disobeying its edicts on moral behaviour, as when in October 2007 a bomb blew up a beauty salon and 16-year-old Nahid al-Shanbari died when the owners failed to heed Hamas warnings on modesty. In Hamas' moral war, that action could even be viewed as ethical since the civilians were removed from the salon. When 31-year old Rami Ayyad, director of The Teacher's Bookshop operated by the Palestinian Bible Society, was killed in 2007 for crimes against Islam for propagating the Christian faith, what was the extent of the outrage? When, in the civil war between Hamas and Fatah in Gaza, the toll hit almost 600 and two Palestinian women and a child were blown up when explosives being handled by militants went off prematurely in Khan Yunis in 2007 or when Hamas spokesperson, Fathi Hammad, not only defended but celebrated the illegal use of civilians for human shields when he boasted, "For the Palestinian people, death has become an industry, at which women excel, and so do all the people living on this land. The elderly excel at this, and so do the mujahideen and the children. This is why they have formed human shields of the women, the children, the elderly, and the mujahideen, in order to challenge the Zionist bombing machine." ${ }^{33}$ Contrast the media coverage when an Israel shell killed 30 -year old Asma Okal and her two small children, Maria and 8-month old Shahd, in their own garden in July of 2006 (Salem 2006).

Further, compare and contrast the coverage and outrage at Israel compared to the actions of the allies in Afghanistan. In "Operation Enduring Freedom" (OEF) in the campaign against the Taliban in Afghanistan in 2002 led by the United States and its allies, such as Canada, the bombing campaign claimed an estimated 1000-1300 civilian lives based on stringent accounting procedures to offset inevitable hyperbole in reporting civilian casualties, higher than the estimates of civilian deaths in Gaza even by Hamas in a far less densely populated area where civilian casualties would be expected to be far greater ${ }^{34}$ The empirical numbers and strategic and tactical differences had to be taken into account in applying the ethical norms. Just because aerial bombing campaigns may occur at over 20,000 feet, ethical evaluations have to be well grounded. One has to do one's empirical homework and not blast off morally from the heavens. The key variables in the difference were probably the difference in campaign objectives, for Operation Cast Lead did not have as its objective the overthrow of the Hamas regime and former and now current Prime Minister Binyamin Netanyahu criticized both Defence Minister Ehud Barak and Foreign

\footnotetext{
33 http://www.youtube.com/watch? $\mathrm{v}=\mathrm{g} 0 \mathrm{wJ} \times \mathrm{f} 2 \mathrm{nt} 4 \mathrm{Y}$

${ }^{34} \mathrm{Cf}$. Conetta 2002. The comparison in the title is to the 1999 Balkans campaign, Operation Allied Force (OAF) aerial bombing campaign in which approximately half the number of civilians died. The differential death toll was traced to different mission objectives (OEF aimed at removing the Taliban regime and killing or capturing as many Taliban and Al Qaeda cadre as possible whereas there was no effort to overthrow the regime in Serbia or kill civilian leaders), differences in operational and tactical features of each of the bombing campaigns so that even though more accurately targeted explosives-smart GPS directed bombswere used but against far fewer fixed targets but in much less populated region, there were still more unintended civilian casualties, and the mix and technical characteristics of the weapons employed, namely a much higher proportion of naval aircraft and use of B1 and B52 bombers flying at higher altitudes for much longer sorties even though the ethical norms were probably applied more rigorously in Afghanistan compared to Kosovo. Human Rights Watch and Reuters provided similar estimates. http://www.comw.org/ pda/02010ef.html\#appendix1
} 
Minister Tzipi Livni in the Israeli election that followed for failing to make that the objective. ${ }^{35}$ Improved accuracy in targeting since the Afghan aerial campaign and far better intelligence on the ground by the Israelis resulted in far fewer civilian casualties than I for one had expected, though the emphasis on mobile and opportunistic targets, that is targets that are not fixed but which cannot be anticipated, emerge unpredictably and require an immediate response, undoubtedly made the civilian casualty toll much higher than it could have been.

Let me end by examining Amnesty International's Report 2009, "State of the World's Human Rights." ${ }^{36}$ The summary on the Middle East begins with Israel's behaviour in Gaza and only Israel's behaviour, not activities in Iraq, Iran or Syria, though brief reports are contained on these countries in the overall Report. "On 27 December, as 2008 drew to a close, Israeli jets launched an aerial bombardment of the Gaza Strip, where 1.5 million Palestinians live, crowded into one of the most densely populated areas of the planet. In the following three weeks, more than 1,400 Palestinians were killed, including some 300 children, and some 5,000 were wounded. Israeli forces repeatedly breached the laws of war, including by carrying out direct attacks on civilians and civilian buildings and attacks targeting Palestinian militants that caused a disproportionate toll among civilians." Palestinian figures are used authoritatively without an examination of sources of difference. More pointedly, Israel is reported as repeatedly breaching the laws of war as if there had been a trial.

In the report on Palestine, the Al Report noted that, "Both the PA security forces in the West Bank and Hamas security forces and militias in Gaza arbitrarily detained hundreds of members or sympathizers of rival factions without charge or trial and often tortured and otherwise ill-treated detainees. Both security forces used excessive force against demonstrators. Hamas security forces in Gaza killed 24 members of armed clans. During the military offensive launched by Israeli forces on 27 December, Hamas forces and militias abducted political opponents and former detainees alleged to have 'collaborated' with Israeli intelligence services; some were summarily killed, others were beaten or shot in the legs. The PA in the West Bank and Hamas in Gaza continued to clamp down on freedom of expression." Yet there is no suggestion that war crimes even might have been committed.

Amnesty International is one of the most respected human rights advocacy organizations. However, surprisingly, it has not demonstrated great expertise in war crimes or in ius bello norms. Further, war crimes and the ethics applied to war are considerations of prudence in relationship to military objectives and, within that context, evaluating efforts to protect civilians. This is radically different than evaluating human protection from a universal human rights perspective.

The issue of this paper, however, is the difficulty of scholars conducting research in areas where they cannot go and in the aftermath of war when there is a great deal of obscurantism and deliberate cover up. However, the greatest difficulty does not come from the combatants, I suggest, but from human rights advocacy organizations that use their standards to apply to situations where different norms are applicable which are measured and assessed in accordance with different processes. These reports are presumptuous and one-sided in making judgments. If one sets its criticisms of Israel beside its criticisms of the Taliban (Al 2009; its spelling) in Pakistan. Look at the headlining, the findings on war crimes, the depiction of direct attacks on civilians and civilian buildings without the qualifier of what may have been in the buildings, and attacks targeting Palestinian militants

\footnotetext{
35 "Bibi vows to topple Hamas if elected," Jerusalem Post, 3 February 2009.

${ }^{36} \mathrm{http}: / /$ thereport.amnesty.org/en/
} 
that caused a disproportionate toll among civilians without any evaluation of what numbers would have been proportionate or the precedents of war crimes trials that use a different measure than the numbers-that is, whether the actions taken were proportionate to the military objective.

So what is one to do when those with whom you are ostensibly allied engage in research from a very different angle, using very different methods and standards than one's own? I am reminded of Amos Elon's proposition and injunction that the blindness of the right is just a force of nature to be expected and countered whereas the ignorant on the left deserve to be called idiots because they should know better. Like Elon, I confess to a double standard. I expect the right and fanatics in Israel and among the Palestinians to be totally one-sided and disrespectful of norms in general. I do not expect it and condemn it on the idealistic left.

My two youngest children are ardent readers of Adbusters, an anti-consumerasim magazine published in Vancouver. Its May/June issue includes a six page pictorial article by Saeed David Mohammed "Never Again" which pictorially compares the treatment of those in Gaza with the treatment by the Nazis of the Jews in the Warsaw ghetto where the dead police in Gaza following the Israeli attack referred to above is set beside and equated with the Nazi execution of Jewish police in the Warsaw ghetto. Though the author declaims making such comparisons lightly, he nevertheless declares, "When events lend themselves to such comparisons, however, it can almost certainly be said that something is very wrong." Though the author declares explicitly that, "the stated goal of Israel has never been the complete destruction of the Palestinian people," he does suggest that the tactics and policies supported by the state of Israel share a family resemblance, to use a Wittgenstein phrase, that understates the odiousness of the comparison. The differences are so great that one does not know where to start but one can begin with the fact that the Jews in the Warsaw ghetto were not committed to the extermination of Germany, nor were they capable of 7000 rocket attacks deliberately targeting civilians, quite aside from the contentious issue of whether the police deaths were or were not illegal.

I think as scholars we have to rededicate ourselves to a defence of objectivity, of making clear the standards that are applicable in assessing situations, of avoiding identification with those who suffer so much that we sacrifice fairness for understandable empathy, and that we insist that the upholders of human rights norms also uphold standards of research and scholarship since they claim the mantle of researchers.

\section{References}

Adelman, H. (1982a). Canada and the Indochinese Refugees. Regina: Weigl Educational.

Adelman, H. (1982b). Miscounting refugees: case study of Lebanon. Refuge, II, 1.

Adelman, H. (1982c). Homeless refugees and displaced persons in Southern Lebanon resulting from the Israeli invasion of Lebanon, York University, Toronto: Refugee Documentation Project.

Adelman, H. \& Abdi, A. (2003). How long is too long: durable solutions for the Dadaab refugees. For CARE Canada.

Adetunji, J., Walker, P., \& McCarthy, R. (2009). Hamas interior minister reported dead in Gaza attack: Saeed Seyyam killed in air strike, says Hamas, as Israel deals with UN outrage after shellng UN agency. The Guardian, 15 January. http://www.guardian.co.uk/world/2009/jan/15/israel-gaza-offensive-truce-talks.

Arens, M. (1997). Targeting children: rights versus Raelpolitik. In T. Kapitan (Ed.), Philosophical perspectives on the Israeli-Palestinian conflict (p. 170). New York: M.E. Sharpe Inc.

Bailey, C. (1985). Dating the arrival of the Bedouin Tribes in the Sinai and Negev. Brill.

Beaumont, P. (2009). Israel admits its troops may have used phosphorus shells in Gaza. The Guardian, 21 January. 
Bronner, E. (2009). Israel puts media clamp on Gaza. New York Times 6 January. http://www.nytimes.com/ 2009/01/07/world/middleeast/07media.html.

Conetta, C. (2002). Operation Enduring Freedom: why a higher rate of civilian bombing casualties. Project on Defense Alternatives Briefing Report \#13, 18 January.

Darnstädt, T., \& Schult, C. (2009). Did Israel commit war crimes in Gaza? Der Spiegel online, 26 January

Downs, G., \& Stedman, S. J. (2001). "Evaluating the international implementation of peace agreements in civil wars". In S. J. Stedman, D. S. Rothchild \& E. M. Cousens (Eds.), Ending civil wars: the implementation of peace agreements. New York: International Peace Academy.

Erlanger, S. (2009a) A Gaza war full of traps and trickery. The New York Times, 10.01.2009. http://www. nytimes.com/2009/01/11/world/middleeast/11hamas.html?pagewanted=1\&_r=2\&sq=Gaza\%20war\% $20 f u l l \% 20 \mathrm{of} \% 20$ tra.

Erlanger, S. (2009b). Weighing crimes and ethics in the fog of war. New York Times, 18 January.

Feldman, Y. \& Blau, U. (2009). Haaretz, 31 January. http://www.haaretz.com/hasen/spages/1059925.html.

Foucault, M. (1986). Power/Knowledge in Selected Interviews. New York: Longman.

Harel, A. (2009a). IDF: Hamas beginning to desert; army steps up Gaza op. Haaretz, 11 January. http://www. haaretz.com/hasen/spages/1054245.html.

Harel, A. (2009b) IDF: 600 Hamas men, 309 civilians died in Gaza offensive, 28 March. http://www.haaretz. com/hasen/spages $/ 1073770 . \mathrm{html}$.

Harel, A. (2009c). UN backtracks on claim that deadly IDF strike hit Gaza school. Haaretz 3 February.

Hider, J. \& Sugden, J. (2009). Barack Obama breaks silence after Gaza UN school strike. The Australian, 7 January. http://www.theaustralian.news.com.au/story/0,25197,24882896-2703,00.html.

Khan, N. (2009). Suicide bomber kills 21 Afghan police officers. Associate Press, 2 February.

Macintyre, D. \& Sengupta, K. (2009). Massacre of innocents as UN school is shelled. The Independent (UK), 7 Jamuary. http://www.independent.co.uk/news/world/middle-east/massacre-of-innocents-as-unschool-is-shelled-1230045.html.

Martin, P. (2009). Account of Israeli attack doesn't hold up to scrutiny. Globe and Mail, 29 January 2009.

Pease, B. (2002). Rethinking empowerment: a postmodern reappraisal for emancipatory practice. British Journal of Social Work, 32, 135-147.

Princeton Refugee Initiative (2005) Protracted refugee situations: a case analysis of Kakuma camp. Princeton University.

Salem, S. A. (2006). Mother and two children killed in Israeli attack on Gaza. Electronic Intifada 7/31/2006 http://electronicintifada.net/v2/article5359.shtml.

Shamir, S. (2009). UN official: Israel should probe shelling which damaged UN buildings in Gaza. Haaretz, 22 January.

Times Online. (2009). UN headquarters in Gaza hit be Israeli 'white phosphorous' shells. 15 January. http:/l www.timesonline.co.uk/tol/news/world/middle_east/article5521925.ece.

Walzer, M. (1997). Just and unjust wars: a moral argument with historical illustrations (2nd ed., p. 135). New York: Basic Books.

Weiner, J. R., \& Bell, A. (2008). International law and fighting in Gaza. MESI, Legacy Heritage Fund, 29 December. http://www.jcpa.org/text/puzzle1.pdf. 